\title{
Hybrid $\mathrm{ZnO} / \mathrm{TiO}_{2}$ Loaded in Electrospun Polymeric Fibers as Photocatalyst
}

\author{
Evando S. Araújo, ${ }^{1,2}$ Juliano Libardi, ${ }^{2,3}$ Pedro M. Faia, ${ }^{2}$ and Helinando P. de Oliveira ${ }^{1}$ \\ ${ }^{1}$ Institute of Materials Science, Federal University of Sao Francisco Valley, 48920-310 Juazeiro, BA, Brazil \\ ${ }^{2}$ CEMUC, Electrical and Computers Engineering Department, Faculty of Sciences and Technology of The University of Coimbra, \\ Polo 2, Pinhal de Marrocos, 3030-290 Coimbra, Portugal \\ ${ }^{3}$ Physics Department, Technological Institute of Aeronautics (ITA), Praça Marechal Eduardo Gomes 50, \\ 12228-900 São José dos Campos, SP, Brazil
}

Correspondence should be addressed to Helinando P. de Oliveira; helinando@gmail.com

Received 17 October 2015; Revised 13 November 2015; Accepted 18 November 2015

Academic Editor: Roberto Comparelli

Copyright (C) 2015 Evando S. Araújo et al. This is an open access article distributed under the Creative Commons Attribution License, which permits unrestricted use, distribution, and reproduction in any medium, provided the original work is properly cited.

\begin{abstract}
Hybrid $\mathrm{ZnO} / \mathrm{TiO}_{2}$ nanoparticles were applied as potential photocatalyst agents incorporated into electrospun fibers of enteric block copolymers. The resistance of fibers avoids aggregation and contributes to prolonged action of semiconductor nanoparticles under continuous light irradiation. Such behavior is attributed to the minimal aggregation degree and elevated efficiency of photodegradation of modified nanoparticles in comparison with pristine ones. Hybrid $\mathrm{ZnO} / \mathrm{TiO}_{2}$ in nanofibers contributes to the association of different mechanisms such as $\mathrm{N}$-deethylation and cleavage of dye molecules applied in the overall process of photodegradation.
\end{abstract}

\section{Introduction}

Metal oxide-based nanostructures have been progressively reported in the literature as important candidates for different applications such as fuel cells [1], solar cells [2, 3], batteries, sensors [4-6], bactericidal agents, self-cleaning coatings, deodorization, and catalysis/photocatalysis $[7,8]$. Relative to the environmental remediation, photocatalysis represents a potential photochemical procedure based on advanced oxidative process (AOP) which depends on the production of free radicals such as the hydroxyl ${ }^{\circ} \mathrm{OH}$ groups, applied in treatment of organic pollutants present in the water. Semiconductor-based photocatalysts are activated by absorption of photons in the UV/visible region with energy superior to the band gap, with posterior migration of electrons from the valence band to the conduction band, while a hole is simultaneously created in the valence band. Photogenerated holes are trapped by hydroxyl groups while electrons are trapped by oxygen species which act in the degradation of dyes, with corresponding production of carbon dioxide, water, and mineral acids [9].
Titanium dioxide $\left(\mathrm{TiO}_{2}\right)$ has been considered a potential candidate for applications involving photocatalytic degradation of environmental pollutants due to its excellent combination of photoactivity and photostability [10-13], high chemical stability in a wide range of $\mathrm{pH}$ values $[12,13]$, and low toxicity. Three different structures are assigned to $\mathrm{TiO}_{2}$ : anatase, rutile, and brookite (band gap of 3.2, 3.0, and $1.9 \mathrm{eV}$, resp.). Conversion of anatase and brookite into rutile is obtained under thermal treatment.

The corresponding photocatalytic activity of semiconductors depends on crystalline structure parameters, namely, crystalline size, particle shape, surface area, and surface hydroxyl groups $[14,15]$. By comparison of the three main polymorphs (anatase, brookite, and rutile) of $\mathrm{TiO}_{2}$, the literature indicates that anatase phase corresponds to the most efficient phase for photocatalytic application [16]. In addition, surface modification represents a relevant procedure which contributes to the improvement in the photocatalytic activity of semiconductor nanoparticles for different crystalline configuration. 
Zinc oxide $(\mathrm{ZnO})$ is another conventional material applied in photocatalysis. Similar mechanisms of photodegradation compared to that reported for $\mathrm{TiO}_{2}$ have been attributed to $\mathrm{ZnO}$. Furthermore, $\mathrm{ZnO}$ has additional properties such as relative low cost, high reactivity, and nontoxicity which favors its use in photocatalysis $[17,18]$.

The development of semiconductor-semiconductor (SS) heterojunction improves the photocatalytic activity of resulting material. Due to the oxygen vacancy in both semiconductors $\left(\mathrm{ZnO}\right.$ and $\left.\mathrm{TiO}_{2}\right)$, filled midgap states below conduction band edge are created (Fermi level near to the conduction band), characterizing both materials as n-type semiconductors.

As a consequence, the heterojunction provided by incorporation of zinc in $\mathrm{TiO}_{2}$ nanostructure can be considered as a non-p-n type (most suitable for photocatalytic application). The improvement in the photocatalytic activity of heterostructure is due to the transference of electrons from conduction band of $\mathrm{ZnO}$ to $\mathrm{TiO}_{2}$ and holes from valence band of $\mathrm{TiO}_{2}$ to $\mathrm{ZnO}$. This process is favored by internal field allowing high concentration of electrons and holes to be available for redox reactions, since separation tends to reduce the recombination rate [19].

As a result, $\mathrm{ZnO} / \mathrm{TiO}_{2}$ hybrid nanocomposites introduce synergistic effect on photocatalytic activity for degradation of organic substances in comparison with isolated semiconductors [20-26].

It is noteworthy that recent studies reported that adequate incorporation of semiconductor nanostructures with suitable materials optimize the properties of resulting hybrid material [27-31], due to the strong interaction and subsequent minimal aggregation. As a consequence, enhancement in the photocatalytic activity results from minimal rate of electronhole recombination [32].

The incorporation of modified $\mathrm{ZnO} / \mathrm{TiO}_{2}$ particles into electrospun fibers of polymeric matrix introduces interesting advantages regarding the higher surface area/volume ratio in comparison with the dispersion of nanoparticles in solution [33]. Particularly, the dispersion of particles in $\mathrm{pH}$-dependent polymeric matrix preserves the distribution of nanoparticles under acidic condition, which allows a more prolonged activity of photocatalytic agents.

In this work, authors have synthesized and characterized electrospun fibers of block copolymers of poly(methacrylic acid-co-methyl methacrylate) incorporating modified nanoparticles of $\mathrm{ZnO} / \mathrm{TiO}_{2}$, where photocatalytic activity was afterwards applied in the photodegradation of rhodamine B using incident visible light, characterizing a new class of visible light-driven photocatalysts.

\section{Materials and Methods}

Poly(methacrylic acid-co-methyl methacrylate) 1:1 (Eudragit L 100 (EDGT), Evonik Industries), titanium dioxide (Sigma Aldrich $\mathrm{TiO}_{2}$ nanopowder, anatase, with medium particle size of $21 \mathrm{~nm}$, purity of $99.5 \%$ and bandgap of $3.2 \mathrm{eV})$, zinc acetate dihydrate $\left(\mathrm{C}_{4} \mathrm{H}_{6} \mathrm{O}_{4} \mathrm{Zn} \cdot 2 \mathrm{H}_{2} \mathrm{O}\right)$ (Sigma Aldrich), and rhodamine $\mathrm{B}$ (Vetec) were used as received.
The morphology was analyzed using scanning electron microscopy (Hitachi TM1000) with an accelerating voltage of $20 \mathrm{kV}$. XRD diffraction pattern was performed by means of DRX Equinox 1000, Inel, while absorbance was measured using a Hach DR5000 spectrophotometer. All experiments were conducted at $25^{\circ} \mathrm{C}$. The size of nanoparticles $\left(\mathrm{TiO}_{2}\right.$ and hybrid $\mathrm{ZnO} / \mathrm{TiO}_{2}$ ) and zeta potential of dispersion in alcoholic solution were determined using Zeta Sizer Malvern (Nano ZS90).

Raman spectroscopy was performed considering the asprepared electrospun fibers in order to identify the corresponding structure of the resulting $\mathrm{ZnO} / \mathrm{TiO}_{2}$ hybrid nanoparticles, using a Raman spectrometer (LabRam Horiba Evolution) with a $532 \mathrm{~nm}$ laser.

2.1. Preparation of Modified $\mathrm{TiO}_{2}\left(\right.$ Hybrid $\left.\mathrm{ZnO} / \mathrm{TiO}_{2}\right)$. Hybrid $\mathrm{ZnO} / \mathrm{TiO}_{2}$ nanoparticles were synthesized by surface modification of $\mathrm{TiO}_{2}$ provided by zinc incorporation. With this aim, a relative ratio of $90 \%: 10 \%$ (in mol) of $\mathrm{TiO}_{2}$ and zinc acetate in $80 \mathrm{~mL}$ of methanol, respectively, was prepared and vigorously stirred at $70^{\circ} \mathrm{C}$ for 1 hour (for complete evaporation of solvent). After the impregnation of zinc acetate on $\mathrm{TiO}_{2}$ surface, the resulting material was thermally treated in an oven at $700^{\circ} \mathrm{C}$ (heating scan rate of $10^{\circ} \mathrm{C} / \mathrm{min}$ ) for 1 hour. Similar procedure is applied for production of rutile, with thermal treatment of anatase at $700^{\circ} \mathrm{C}$ (heating scan rate of $10^{\circ} \mathrm{C} / \mathrm{min}$ ) for 1 hour.

2.2. Electrospun Fibers Production. Polymeric solution was prepared at $25^{\circ} \mathrm{C}$, by introduction of $1.4 \mathrm{~g}$ of Eudragit L-100 (EDGT) in $6 \mathrm{~mL}$ of ethyl alcohol, which was stirred for 10 minutes until complete dispersion of polymer.

Different concentration of $\mathrm{TiO}_{2}$ and modified $\mathrm{TiO}_{2}(0 \%$, $2 \%, 4 \%$, and $6 \%$, in wt) were added to EDGT solution and maintained under fixed pressure in a flux of $166 \mu \mathrm{L} / \mathrm{min}$ in the absence of external electric field (an optimized condition for continuous fiber production) [34].

The basic setup for fibers production is composed by a spinneret connected to a high voltage source and a grounded target. The capillary is a metal cylinder compartment with uniform diameter of $0.7 \mathrm{~mm}$ with planar interface (the extremity of spinneret is cut in a plane parallel to the grounded target).

An electrical excitation from DC high voltage source $(15 \mathrm{kV})$ is established between the needle and the grounded target (the needle extremity and the ground plane are separated by $10 \mathrm{~cm}$ ). During the deposition time, which lasts for 5 minutes, a sample holder (metallic flat surface disposed on the surface of the grounded target plane) collects the ejected fibers.

For quantitative determination of relative concentration of semiconductor (anatase, rutile, and $\mathrm{ZnO} / \mathrm{TiO}_{2}$ ) in Eudragit L-100 electrospun fibers, we have explored an important property of resulting fibers: carboxylic groups of Eudragit L100 became ionized at alkaline $\mathrm{pH}$. As a result, the repulsion established between negative charges of carboxylate groups provides the swelling of structure allowing the diffusion of encapsulated material in direction to the solution $[35,36]$. The determination of nanoparticles concentration in aqueous 
solution is established according to standard spectrophotometric procedure based on Beer-Lambert's law. Calibration curves return linear dependence in the plot of absorbance peak versus relative concentration of material. Based on this linear relationship, the corresponding concentration can be calculated from direct measurement of absorbance at characteristic peak $[37,38]$.

Using this property, it was possible to measure the encapsulated nanoparticles amount in microfibers from direct measurement of absorbance of resulting solution. With this aim, $10 \mathrm{mg}$ of electrospun fibers (at different concentration of semiconductor nanoparticles) was soaked into $5 \mathrm{~mL}$ of sodium hydroxide aqueous solution $(\mathrm{pH} 7.0)$ under continuous stirring, until complete dispersion of the fibers was observed, for posterior determination of characteristic absorbance (direct measurement of encapsulation efficiency).

2.3. Statistical Data Treatment. The statistical data treatment was performed using software Minitab 14 (statistics package) and ImageJ (public-domain image processing and analysis program developed at US National Institute of Health (NIH)) $[39,40]$. For data analysis, three independent SEM images of resulting fibers were examined, for each relative concentration of $\mathrm{EDGT} / \mathrm{TiO}_{2}$ and $\mathrm{EDGT} /\left(\mathrm{ZnO} / \mathrm{TiO}_{2}\right)$ (SEM images of 30 different group of fibers).

From these images, and for each of the 8 sets of samples, the average fiber diameter $(\bar{d})$ and corresponding standard deviation $\left(S_{\bar{d}}\right)$ were determined. Kolmogorov-Smirnov (KS) hypothesis [41] with significance $(\alpha)$ of 0.05 was established for identification of normal distribution diameter. In addition, a hypothesis test with unknown population means and variance (significance level $(\alpha)$ of 0.05$)$ was realized for detection of difference between mean diameter of fibers produced with anatase $\mathrm{TiO}_{2}$ and that with modified $\mathrm{TiO}_{2}$, as a function of concentration of photocatalyst $(2,4$, and $6 \mathrm{wt} \%)$.

2.4. Photocatalytic Activity Test. Photodegradation procedure was conducted using a standard experimental setup, as follows: $10 \mathrm{mg}$ of semiconductor-loaded fibers was soaked into a dye aqueous solution $(5 \mathrm{~mL}$ of $1 \mu \mathrm{M}$ of rhodamine B aqueous solution at $\mathrm{pH} 7.0$ and disposed in a cylindrical reactor, $10 \mathrm{~mL}$ beaker) which was maintained under continuous stirring under dark conditions for $1 \mathrm{~h}$ allowing the adsorption of the dye at the surface of the fibers. Continuous incidence of white light $(60 \mathrm{~W}$, disposed at $30 \mathrm{~cm}$ from reactor) avoids variation in the temperature of solution. Aliquots of the solution were removed at fixed interval of time of 30 minutes from the reactor for optical characterization in order to measure and establish the kinetics of photodegradation process. The photocatalyst remains in contact with dye during complete process of light incidence.

\section{Results and Discussion}

\subsection{Characterization of Semiconductor Nanoparticles}

3.1.1. Raman Spectrum. Raman spectrum of $\mathrm{ZnO}, \mathrm{TiO}_{2}$, and hybrid $\mathrm{ZnO} / \mathrm{TiO}_{2}$ nanopowder is shown in Figure 1 .

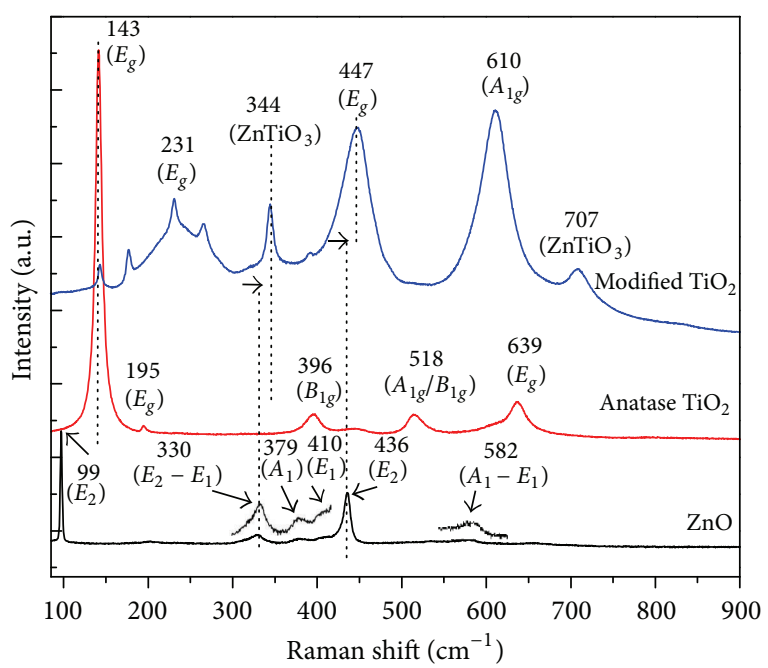

Figure 1: Raman spectrum of $\mathrm{ZnO}$, anatase, and hybrid $\mathrm{ZnO} / \mathrm{TiO}_{2}$ nanopowder.

Regarding the $\mathrm{ZnO}$ spectrum, bands at $330 \mathrm{~cm}^{-1}$ (secondorder Raman processes, $E_{2}-E_{1}$ vibration modes), $436 \mathrm{~cm}^{-1}$ ( $E_{2}$ high vibration mode, associated with oxygen atoms), and $582 \mathrm{~cm}^{-1}\left(A_{1}-E_{1}\right.$ modes [42-44]) are attributed to $\mathrm{ZnO}$ nanocrystals. Bands at $99 \mathrm{~cm}^{-1}\left(E_{2}\right.$ low, associated with $\mathrm{Zn}$ sublattice), $379 \mathrm{~cm}^{-1}\left(A_{1}\right)$, and $410 \mathrm{~cm}^{-1}\left(E_{1}\right)$ characterize the crystalline structure of $\mathrm{ZnO}[42,45]$.

The Raman spectrum of anatase is characterized by six different vibration modes namely $\left(3 E_{g}+2 B_{1 g}+1 A_{1 g}\right)$, at $143 \mathrm{~cm}^{-1}, 195 \mathrm{~cm}^{-1}$, and $396 \mathrm{~cm}^{-1}$ (assigned to $E_{g}$ modes) at $518 \mathrm{~cm}^{-1}\left(A_{1 g} / B_{1 g}\right.$ unresolved doublet) [43] and at $639 \mathrm{~cm}^{-1}$ $\left(A_{1 g}\right)$, as described in [46-50].

On the other side, the spectrum of the hybrid $\mathrm{ZnO} / \mathrm{TiO}_{2}$ composite, obtained under thermal treatment at $700^{\circ} \mathrm{C}$, indicates that the dominant crystalline phase (anatase) was converted into rutile, due to the substitution of the characteristic peaks of anatase by rutile ones: $\left(2 E_{g}+1 B_{1 g}+1 A_{1 g}\right)$ mode at $143 \mathrm{~cm}^{-1}$ and at $231 \mathrm{~cm}^{-1}\left(E_{g}\right)$, (multiproton process) at $447 \mathrm{~cm}^{-1}\left(E_{g}\right)$ [48], and $\left(A_{1 g}\right)$ at $610 \mathrm{~cm}^{-1}$ [51-53].

Beyond the influence of thermal treatment over conversion of anatase into rutile, $\mathrm{Zn}^{2+}$ ions accelerate the transition kinetics, providing additional oxygen vacancies due to the substitution of $\mathrm{Ti}^{4+}$ by $\mathrm{Zn}^{2+}$ [54] which results in the increase of the disorder of the atomic structure of $\mathrm{TiO}_{2}$ [22]. Characteristic bands of pristine $\mathrm{ZnO}$ are not only blue shifted to $344 \mathrm{~cm}^{-1}$ and $447 \mathrm{~cm}^{-1}$ as the intensity of the peaks increases, as a consequence of the surface modification. This behavior is typically assigned to the compression established by $\mathrm{ZnO}$ atoms over the $\mathrm{TiO}_{2}$ structure $[55,56]$.

The level of interaction established between $\mathrm{ZnO}$ and $\mathrm{TiO}_{2}$ was also observed in additional bands, particularly at 344 and $707 \mathrm{~cm}^{-1}$ in the case of hybrid $\mathrm{ZnO} / \mathrm{TiO}_{2}$ particles, which can be attributed to the presence of $\mathrm{ZnTiO}_{3}$ [57].

3.1.2. Powder X-Ray Diffractogram. The XRD of hybrid $\mathrm{ZnO} / \mathrm{TiO}_{2}$ nanopowder is shown in Figure 2. Sharp peaks 


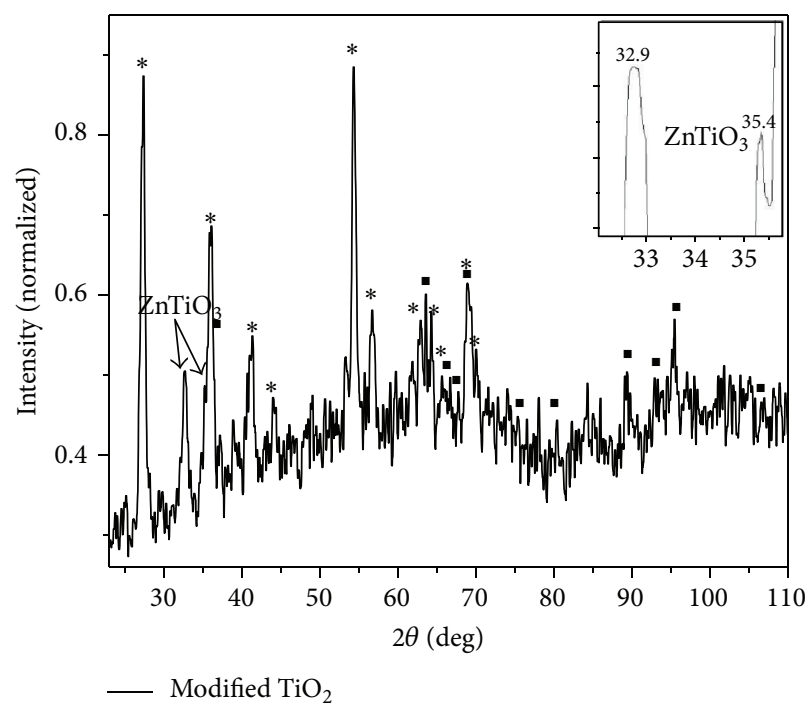

FIGURE 2: XRD of modified $\mathrm{TiO}_{2}$ (hybrid $\mathrm{ZnO} / \mathrm{TiO}_{2}$ composite) nanopowder. The symbol “*” identifies characteristic phases of rutile, while $\mathrm{ZnO}$ peaks are represented by “"”. In the inset, peaks confirm the presence of $\mathrm{ZnTiO}_{3}$.
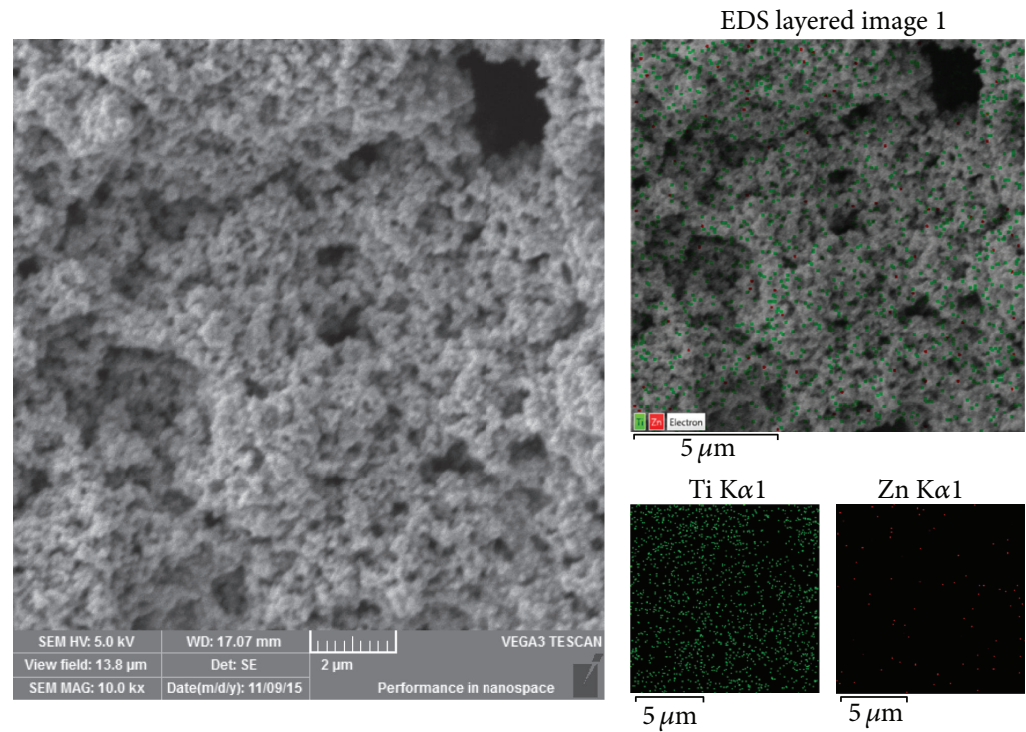

FIGURE 3: SEM image and overlaid EDS data of resulting hybrid $\mathrm{ZnO} / \mathrm{TiO}_{2}$ nanopowder with corresponding identification of $\mathrm{Zn}$ and Ti.

are observed at $2 \theta=27.50^{\circ}, 36.16^{\circ}, 41.33^{\circ}, 44.13^{\circ}, 54.37^{\circ}$, $56.79^{\circ}, 62.89^{\circ}, 64.27^{\circ}, 65.69^{\circ}, 69.12^{\circ}$, and $69.98^{\circ}$, all assigned to tetragonal crystalline structure of rutile [58], while peaks at $36.31^{\circ}, 63.40^{\circ}, 66.74^{\circ}, 67.81^{\circ}, 68.96^{\circ}, 76.60^{\circ}, 80.48^{\circ}, 89.44^{\circ}$, $93.28^{\circ}, 95.54^{\circ}$, and $106.96^{\circ}$ are attributed to the hexagonal crystalline structure of $\mathrm{ZnO}$ (according JCPDS Card number 36-1451).

In agreement with the previously reported peaks in the Raman spectrum, additional XRD peaks due to the $\mathrm{ZnTiO}_{3}$ are observed at $53.5^{\circ}$ and $61.9^{\circ}$, as described by Nolan et al. [59].

3.1.3. Size of Particles and Zeta Potential. The dispersion of $\mathrm{TiO}_{2}$ nanoparticles in ethanol returned particles size distribution in order of $(22.41 \pm 4.93) \mathrm{nm}$ and zeta potential of $(5.89 \pm 0.11) \mathrm{mV}$ which is in agreement with information of manufacturer (diameter of $21 \mathrm{~nm}$-determined by TEM). The value of particle size of hybrid $\mathrm{ZnO} / \mathrm{TiO}_{2}$ in ethanol is in order of $(92.02 \pm 16.15) \mathrm{nm}$ and corresponding zeta potential of $(0.77 \pm 0.53) \mathrm{mV}$. The strong variation in the diameter and zeta potential represent evidences that morphology of particles is affected by surface modification. SEM of resulting hybrid $\mathrm{ZnO} / \mathrm{TiO}_{2}$ nanoparticles (shown in the Figure 3) indicates that interaction between $\mathrm{Zn}$ and $\mathrm{Ti}$ is established along aggregates of nanoparticles, as identified in EDS data.

3.2. Morphology of Semiconductor-Loaded Electrospun Fibers ( $\mathrm{TiO}_{2}$ and Hybrid $\mathrm{ZnO} / \mathrm{TiO}_{2}$ Particles). The relative concentration of dispersed nanoparticles in fibers (measured from absorbance peak $(A)$ at $340 \mathrm{~nm}$, anatase, and $400 \mathrm{~nm}$, hybrid 

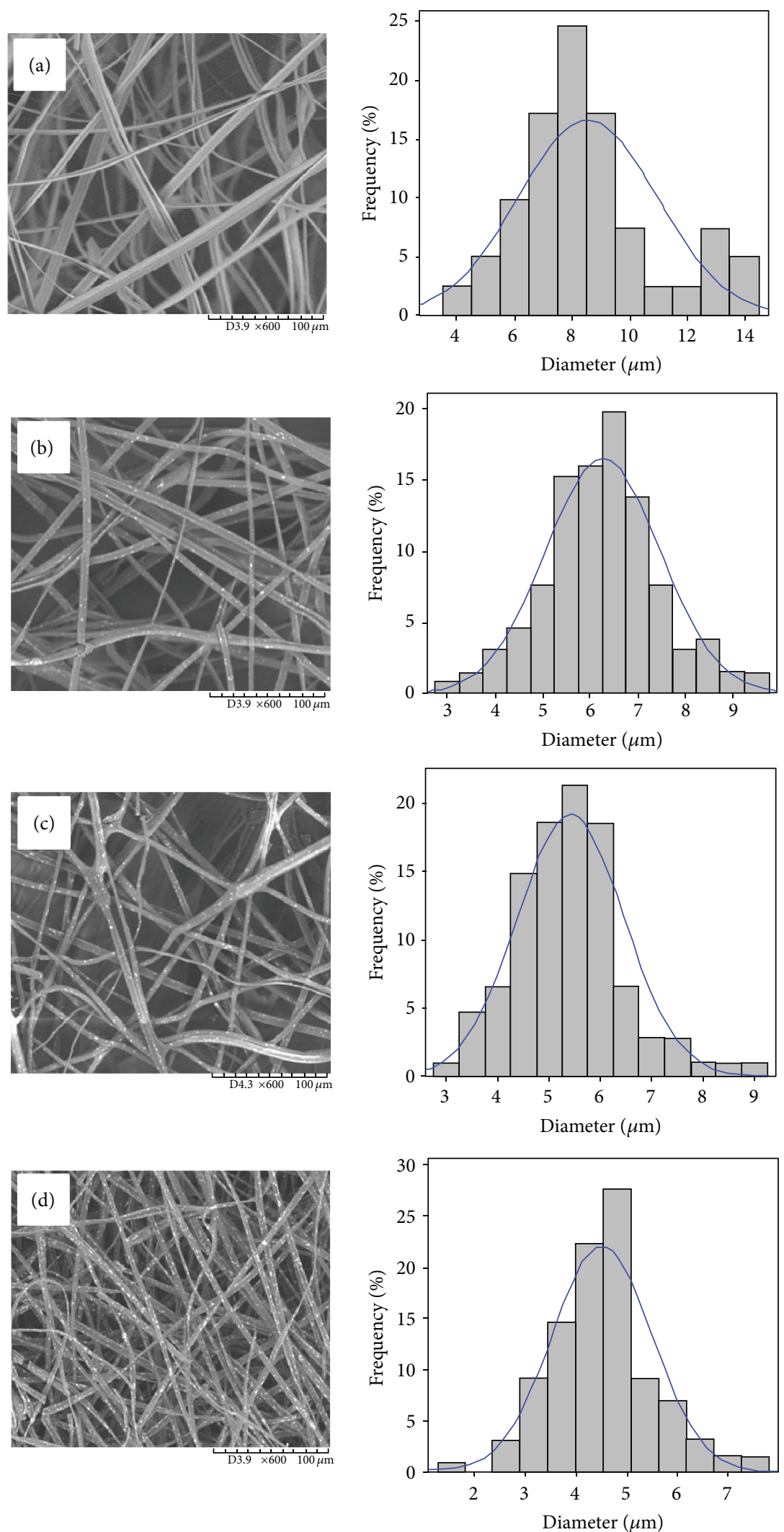

FIGURE 4: SEM images of electrospun fibers with increasing concentration of loaded- $\mathrm{TiO}_{2}$ (pristine EDGT (a), $2 \mathrm{wt} \% \mathrm{of} \mathrm{TiO}_{2}$ in EDGT fibers (b), $4 \mathrm{wt} \%$ of $\mathrm{TiO}_{2}$ in EDGT fibers (c), and $6 \mathrm{wt} \%$ of $\mathrm{TiO}_{2}$ in EDGT fibers (d)). 


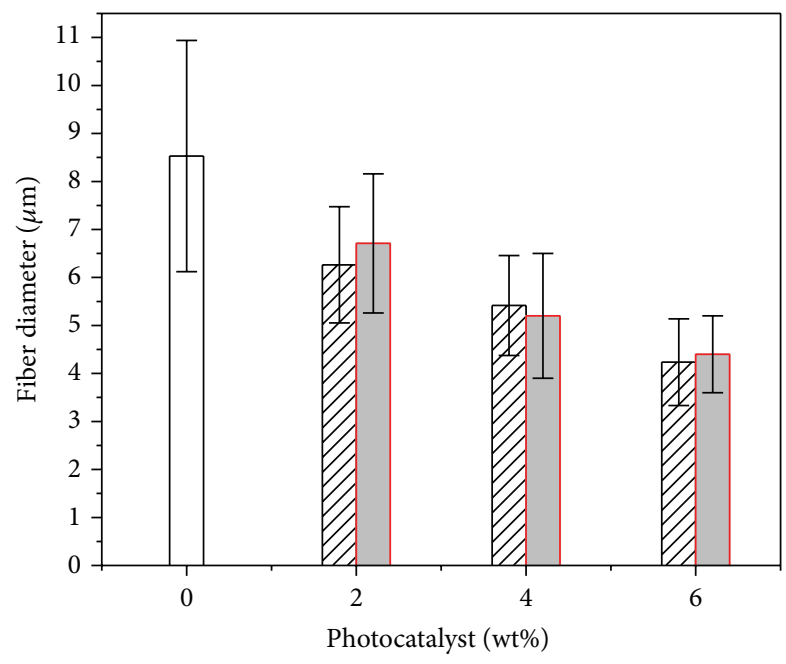

ZZA Anatase $\mathrm{TiO}_{2}$ Modified $\mathrm{TiO}_{2}$

FIGURE 5: Diameter of resulting electrospun fibers as a function of the relative concentration of additives.

$\mathrm{ZnO} / \mathrm{TiO}_{2}$ ) was determined from calibration curve. Results indicate that $A=0.08+7.60 C$ (anatase) and $A=0.05+7.57 C$ (hybrid $\left.\mathrm{ZnO} / \mathrm{TiO}_{2}\right)\left(R^{2}=0.99\right)$. Corresponding mass of additives in $10 \mathrm{mg}$ of fibers was $(0.13 \pm 0.04) \mathrm{mg},(0.33 \pm$ $0.04) \mathrm{mg}$, and $(0.54 \pm 0.04) \mathrm{mg}$ relative to samples prepared with 2,4 , and $6 \mathrm{wt} \%$ of anatase and $(0.19 \pm 0.03) \mathrm{mg},(0.32 \pm$ $0.03) \mathrm{mg}$, and $(0.47 \pm 0.03) \mathrm{mg}$ for samples prepared with 2 , 4 , and $6 \mathrm{wt} \%$ of hybrid $\mathrm{ZnO} / \mathrm{TiO}_{2}$.

Figure 4 summarizes the influence of $\mathrm{TiO}_{2}$ concentration on morphology of the resulting electrospun fibers (SEM images and data analysis). As can be seen from SEM images of Figure 4, electrospun fibers are free from beads incorporation, due to the homogeneous dispersion of semiconductor particles along the entire resulting structures. Statistical analysis of fibers indicates that progressive increase in the nanoparticles concentration $\left(\mathrm{TiO}_{2}\right.$ anatase) contributes to the reduction of the fibers diameter from $8.5 \mu \mathrm{m}$ (pristine) to $4.2 \mu \mathrm{m}$ ( $16 \mathrm{wt} \%$ of anatase), which consequently increases the surface/volume ratio. Corresponding results for hybrid $\mathrm{ZnO} / \mathrm{TiO}_{2}$ particles are in agreement with previously reported data. The dependence of the fibers diameter, with both additives (anatase and hybrid $\mathrm{ZnO} / \mathrm{TiO}_{2}$ ) is shown in Figure 5.

Normality test indicates that all of samples are characterized by $p$ value $>\alpha$, which corresponds to a normal distribution. In addition, hypothesis test returns a $p$ value $>\alpha$. It means that measurement of fiber diameter is independent of type of additive at corresponding concentration (anatase and hybrid $\mathrm{ZnO} / \mathrm{TiO}_{2}$ ).

By looking at Figure 5, it is possible to confirm that the diameter of electrospun fibers is progressively reduced with increasing introduction of additive and, for both additives, with direct consequence on the available surface area for semiconducting action.

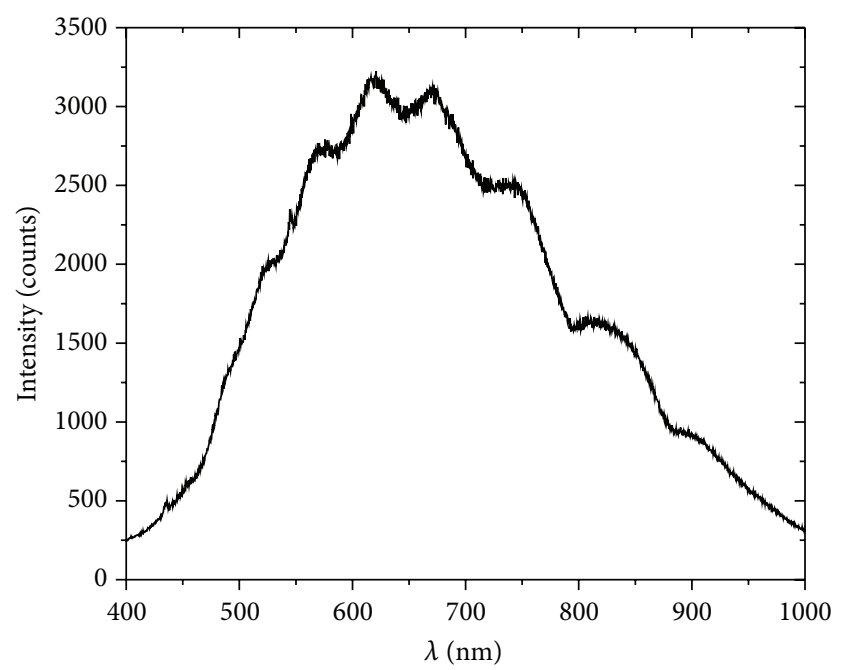

FIGURE 6: Emission spectrum of white light applied during excitation of dye.

3.3. Photodegradation Process. Continuous incidence of white light (emission spectrum shown in Figure 6), on the aqueous solution containing the dye (rhodamine $\mathrm{B}, 1 \mu \mathrm{M}$ ) and the photocatalyst $(10 \mathrm{mg}$ of resulting fibers with photocatalyst), under consideration, was registered, under fixed intervals of time, by means of UV-vis measurement.

The continued action of white light on the dye in the presence of the photocatalyst results in a constant reduction in the characteristic peak in the UV-vis spectrum. Figure 7 shows the spectrum of residues of rhodamine B under continuous light incidence (action of anatase).

As it can be observed from the spectrum (see Figure 7) the decrease in the absorbance has been assigned to the cleavage of molecules due to the progressive photodegradation of species associated with invariance in the peak position. The increase in the relative concentration of semiconductor (Figures 7(a), 7(b), and 7(c)) dispersed in fibers results in the increase of photodegradation rate (verified from the decrease in the absorbance at corresponding interval of time). Comparison with response of rutile (Figure $7(\mathrm{~d})$ ) indicates that low efficiency of degradation has been attributed to the semiconductor, as expected.

The response of hybrid $\mathrm{ZnO} / \mathrm{TiO}_{2}$ particles applied as photocatalyst is shown in Figure 8. An important aspect to be reported concerns the blue shift observed in the spectrum of residues of rhodamine $\mathrm{B}$ at continuous light incidence. It is an indication that initial step of cleavage of dye molecules is followed by N-deethylation (due to blue shift of characteristic peak) and later by the degradation of dye as a result of mutual chemical process.

The comparison of absorbance of residual dye in aqueous solution as a function of time is summarized in Figure 9.

As it can be seen, the relative concentration of residual dye is unaffected by light exposure of dye solution in the absence of photocatalyst (control experiment, EDGT). The increasing amount of semiconductor (anatase, from $2 \mathrm{wt} \%$ to $6 \mathrm{wt} \%)$ dispersed in matrix affects the photocatalytic 


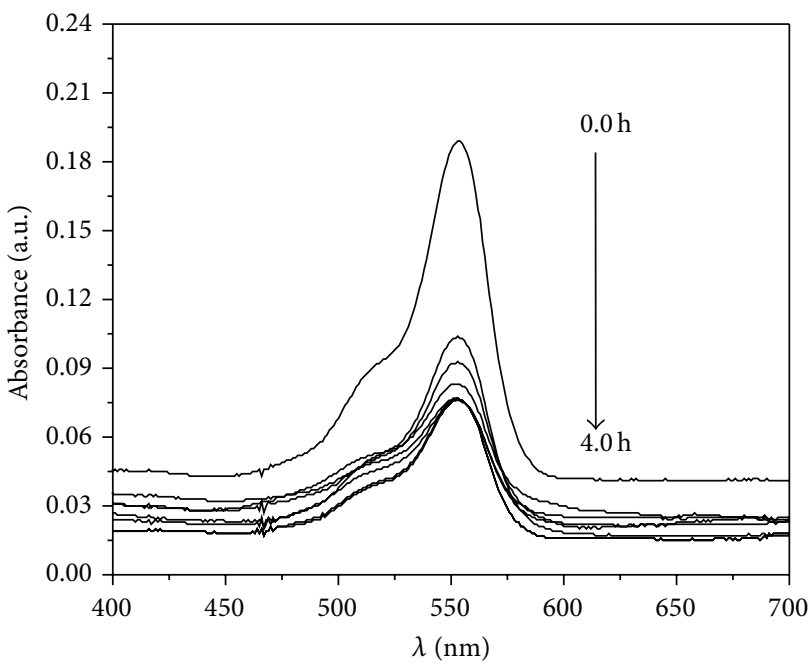

— EDGT: $\mathrm{TiO}_{2}(98: 2, \mathrm{wt} \%)$

(a)

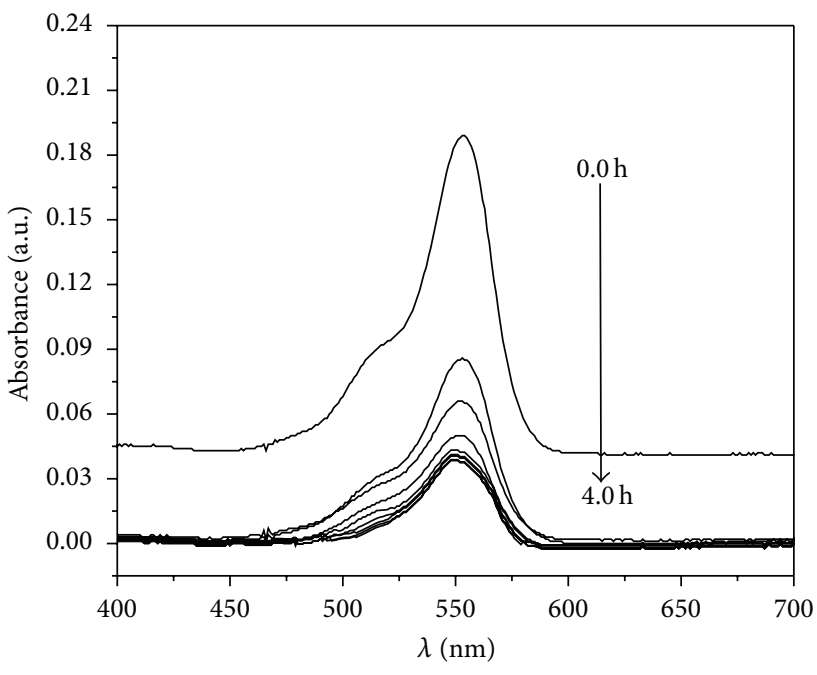

EDGT : $\mathrm{TiO}_{2}(94: 6, \mathrm{wt} \%)$

(c)

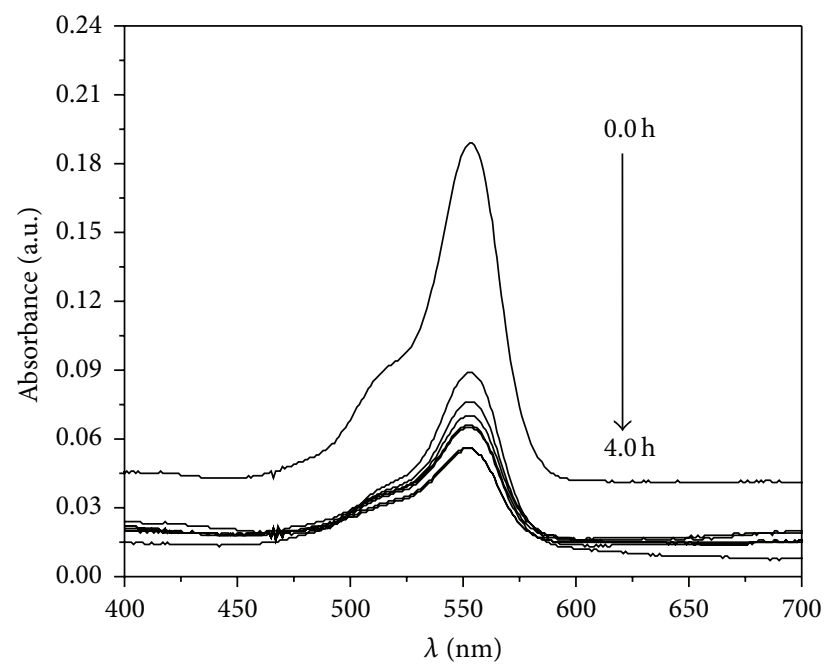

- EDGT: $\mathrm{TiO}_{2}$ (96:4, wt\%)

(b)

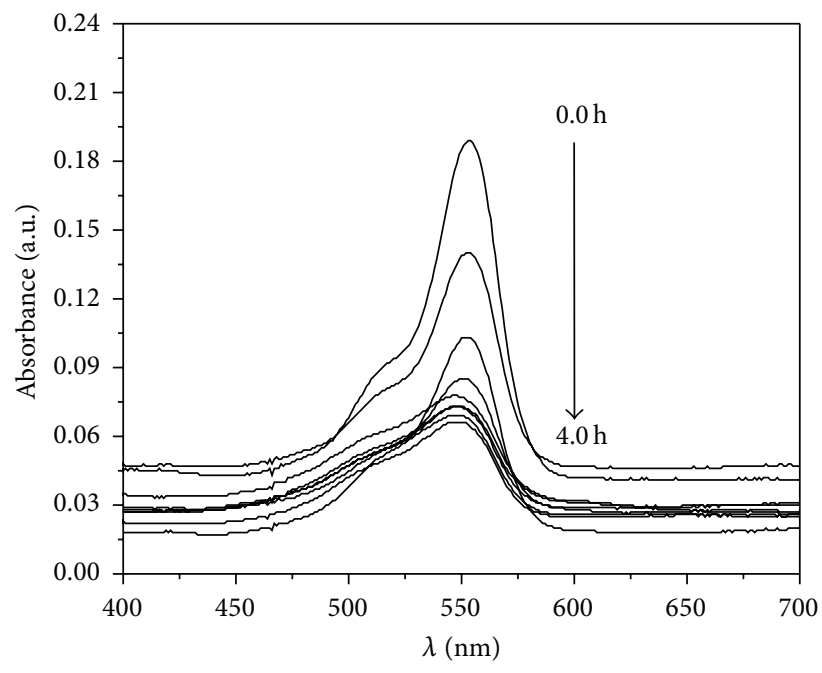

_ EDGT: rutile $\mathrm{TiO}_{2}(94: 6, \mathrm{wt} \%)$

(d)

FiguRE 7: Absorbance spectrum of residues of rhodamine B under continuous incidence of light (successive curves were acquired at fixed interval of time of $30 \mathrm{~min}$ ), using $2 \mathrm{wt} \%$ (a), $4 \mathrm{wt} \%$ (b), and $6 \mathrm{wt} \%$ (c) of anatase and $6 \mathrm{wt} \%$ of rutile (d) in fibers as a photocatalyst.

activity of resulting material and progressively reduces the concentration of dye under continued action of light $(4 \mathrm{~h})$, which reaches reduction in order of $50 \%, 2 \mathrm{wt} \% ; 60 \%, 4 \mathrm{wt} \%$; and $75 \%, 6 \mathrm{wt} \%$ in agreement with corresponding results for rutile. By comparison with the hybrid $\mathrm{ZnO} / \mathrm{TiO}_{2}$, it can be observed that the interaction of both mechanisms results in a more efficient process, in which $90 \%$ of dye is photodegraded after four hours of continuous light incidence. Based on this information, it is possible to define the formulation (hybrid $\mathrm{ZnO} / \mathrm{TiO}_{2}$ )/Eudragit L-100 nanofibers as a potential candidate for efficient photocatalytic activity against rhodamine B.

Superior performance in photocatalytic applications of hybrid $\mathrm{ZnO} / \mathrm{TiO}_{2}$ has been assigned to the coupling effect between semiconductors. Kanjwal et al. [33] reported that efficient charge separation takes place with transference of electrons from conduction band of $\mathrm{ZnO}$ to conduction band of $\mathrm{TiO}_{2}$ and photogenerated holes from valence band of $\mathrm{TiO}_{2}$ to valence band of $\mathrm{ZnO}$, in agreement with typical mechanisms of photocatalysts-based non-p-n type heterojunctions.

\section{Conclusion}

The surface modification of $\mathrm{TiO}_{2}$ provided by $\mathrm{ZnO}$ incorporation and posterior encapsulation in the electrospun fibers provide a potential candidate for photocatalytic agent against organic dyes such as rhodamine $\mathrm{B}$. This conclusion is based on the association of $\mathrm{N}$-deethylation and cleavage of organic dyes, which results in the optimal photodegradation in comparison with electrospun fibers decorated with pristine semiconductors. It is a result of efficient coupling established 


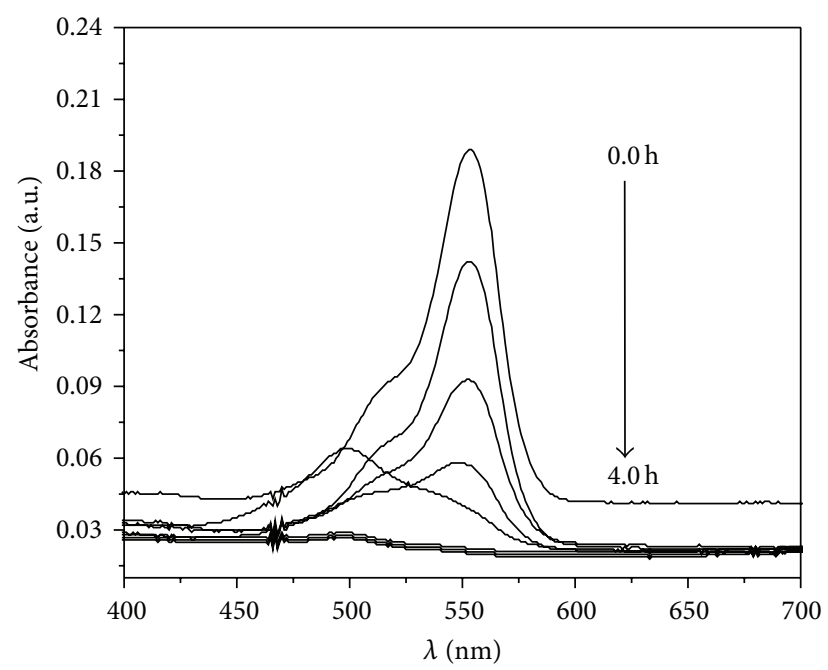

— EDGT: modified $\mathrm{TiO}_{2}(94: 6, \mathrm{wt} \%)$

FIgURE 8: Absorbance spectrum of residues of rhodamine $B$ in the presence of photocatalyst (hybrid $\mathrm{ZnO} / \mathrm{TiO}_{2}$ in fibers) under continuous incidence of light (successive curves were acquired at fixed interval of time of $30 \mathrm{~min}$ ).

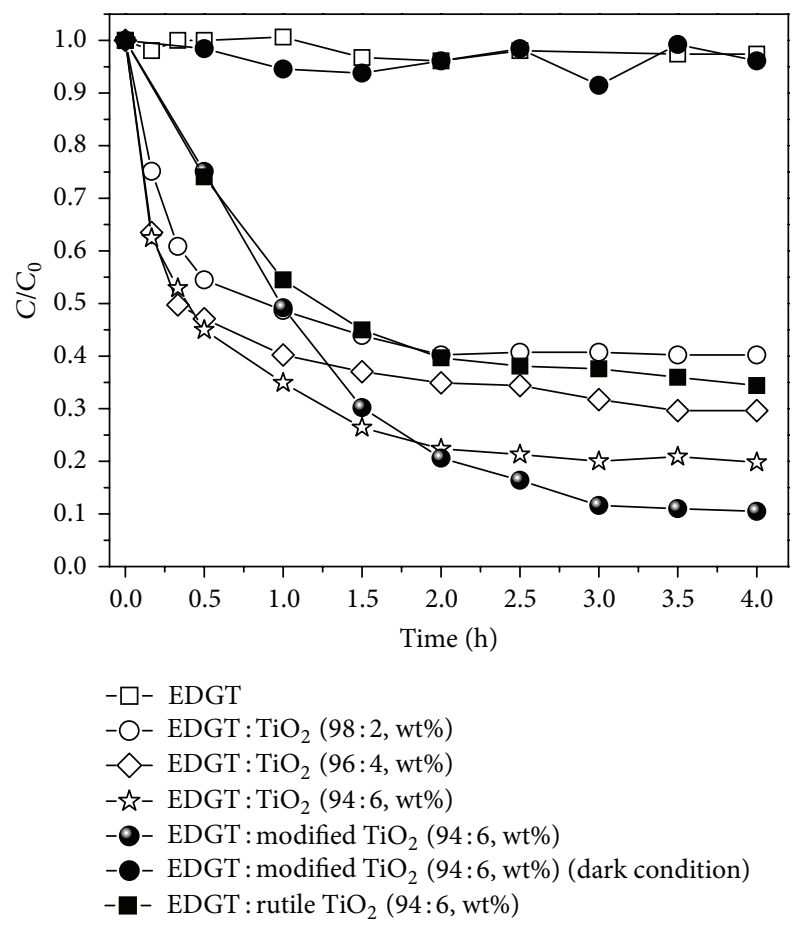

FIGURE 9: Comparison of absorbance peaks of residue of dyes under continuous light incidence in the presence of photocatalyst (anatase, rutile, and hybrid $\mathrm{ZnO} / \mathrm{TiO}_{2}$ in fibers) with control experiment.

between $\mathrm{ZnO}$ and $\mathrm{TiO}_{2}$ with more efficient charge separation and minimal recombination rate.

\section{Conflict of Interests}

The authors declare that there is no conflict of interests regarding the publication of this paper.

\section{Acknowledgments}

This work was partially supported by the Brazilian agencies FINEP, CAPES, FAPESB, and CNPq.

\section{References}

[1] Z. Zhang, J. Liu, J. Gu, L. Su, and L. Cheng, "An overview of metal oxide materials as electrocatalysts and supports for polymer electrolyte fuel cells," Energy \& Environmental Science, vol. 7, no. 8, pp. 2535-2558, 2014.

[2] O. Kluth, G. Schöpe, J. Hüpkes, C. Agashe, J. Müller, and B. Rech, "Modified Thornton model for magnetron sputtered zinc oxide: film structure and etching behaviour," Thin Solid Films, vol. 442, no. 1-2, pp. 80-85, 2003.

[3] A. J. Frank, N. Kopidakis, and J. van de Lagemaat, "Electrons in nanostructured $\mathrm{TiO}_{2}$ solar cells: transport, recombination and photovoltaic properties," Coordination Chemistry Reviews, vol. 248, no. 13-14, pp. 1165-1179, 2004.

[4] W. S. Choi, E. J. Kim, S. G. Seong, Y. S. Kim, C. Park, and S. H. Hahn, "Optical and structural properties of $\mathrm{ZnO} / \mathrm{TiO}_{2} / \mathrm{ZnO}$ multi-layers prepared via electron beam evaporation," Vacuum, vol. 83, no. 5, pp. 878-882, 2009.

[5] Q. Zhang, S. Zhang, C. Xie, C. Fan, and Z. Bai, "'Sensory analysis' of Chinese vinegars using an electronic nose," Sensors and Actuators B: Chemical, vol. 128, no. 2, pp. 586-593, 2008.

[6] P. M. Faia, E. L. Jesus, and C. S. Louro, " $\mathrm{TiO}_{2}: \mathrm{WO}_{3}$ composite humidity sensors doped with $\mathrm{ZnO}$ and $\mathrm{CuO}$ investigated by impedance spectroscopy," Sensors and Actuators B: Chemical, vol. 203, pp. 340-348, 2014.

[7] R. Georgekutty, M. K. Seery, and S. C. Pillai, "A highly efficient Ag-ZnO photocatalyst: synthesis, properties, and mechanism," The Journal of Physical Chemistry C, vol. 112, no. 35, pp. 1356313570, 2008.

[8] K. Nakata and A. Fujishima, " $\mathrm{TiO}_{2}$ photocatalysis: design and applications," Journal of Photochemistry and Photobiology C: Photochemistry Reviews, vol. 13, no. 3, pp. 169-189, 2012.

[9] E. G. L. Oliveira, J. J. Rodrigues, and H. P. de Oliveira, "Influence of surfactant on the fast photodegradation of rhodamine $\mathrm{B}$ induced by $\mathrm{TiO}_{2}$ dispersions in aqueous solution," Chemical Engineering Journal, vol. 172, no. 1, pp. 96-101, 2011.

[10] N. M. Dimitrijevic, Z. V. Saponjic, B. M. Rabatic, and T. Rajh, "Assembly and charge transfer in hybrid $\mathrm{TiO}_{2}$ architectures using biotin-avidin as a connector," Journal of the American Chemical Society, vol. 127, no. 5, pp. 1344-1345, 2005.

[11] B. M. Rabatte, N. M. Dimitrijevic, R. E. Cook, Z. V. Saponjic, and T. Rajh, "Spatially confined corner defects induce chemical functionality of $\mathrm{TiO}_{2}$ nanorods," Advanced Materials, vol. 18, no. 8, pp. 1033-1037, 2006.

[12] S. Liao, H. Donggen, D. Yu, Y. Su, and G. Yuan, "Preparation and characterization of $\mathrm{ZnO} / \mathrm{TiO}_{2}, \mathrm{SO}_{4}^{2-} / \mathrm{ZnO} / \mathrm{TiO}_{2}$ photocatalyst and their photocatalysis," Journal of Photochemistry and Photobiology A: Chemistry, vol. 168, no. 1-2, pp. 7-13, 2004.

[13] R. Comparelli, E. Fanizza, M. L. Curri, P. D. Cozzoli, G. Mascolo, and A. Agostiano, "UV-induced photocatalytic degradation of azo dyes by organic-capped $\mathrm{ZnO}$ nanocrystals immobilized onto substrates," Applied Catalysis B: Environmental, vol. 60, no. 1-2, pp. 1-11, 2005.

[14] C. Bernardini, G. Cappelletti, M. V. Dozzi, and E. Selli, "Photocatalytic degradation of organic molecules in water: photoactivity and reaction paths in relation to $\mathrm{TiO}_{2}$ particles features," 
Journal of Photochemistry and Photobiology A: Chemistry, vol. 211, no. 2-3, pp. 185-192, 2010.

[15] V. Puddu, H. Choi, D. D. Dionysiou, and G. L. Puma, " $\mathrm{TiO}_{2}$ photocatalyst for indoor air remediation: influence of crystallinity, crystal phase, and UV radiation intensity on trichloroethylene degradation," Applied Catalysis B: Environmental, vol. 94, no. 3-4, pp. 211-218, 2010.

[16] K. E. Karakitsou and X. E. Verykios, "Effects of altervalent cation doping of $\mathrm{TiO}_{2}$ on its performance as a photocatalyst for water cleavage," Journal of Physical Chemistry, vol. 97, no. 6, pp. 1184-1189, 1993.

[17] A. Akyol, H. C. Yatmaz, and M. Bayramoglu, "Photocatalytic decolorization of Remazol Red RR in aqueous $\mathrm{ZnO}$ suspensions," Applied Catalysis B: Environmental, vol. 54, no. 1, pp. 1924, 2004.

[18] S. Chakrabarti and B. K. Dutta, "Photocatalytic degradation of model textile dyes in wastewater using $\mathrm{ZnO}$ as semiconductor catalyst," Journal of Hazardous Materials, vol. 112, no. 3, pp. 269278, 2004.

[19] H. Wang, L. Zhang, Z. Chen et al., "Semiconductor heterojunction photocatalysts: design, construction, and photocatalytic performances," Chemical Society Reviews, vol. 43, no. 15, pp. 5234-5244, 2014.

[20] N. Serpone, P. Maruthamuthu, P. Pichat, E. Pelizzetti, and H. J. Hidaka, "Exploiting the interparticle electron transfer process in the photocatalysed oxidation of phenol, 2-chlorophenol and pentachlorophenol: chemical evidence for electron and hole transfer between coupled semiconductors," Journal of Photochemistry and Photobiology A: Chemistry, vol. 85, no. 3, pp. 247-255, 1995.

[21] V. Sukharev and R. Kershaw, "Concerning the role of oxygen in photocatalytic decomposition of salicylic acid in water," Journal of Photochemistry and Photobiology A: Chemistry, vol. 98, no. 3, pp. 165-169, 1996.

[22] S. S. Silva, F. Magalhães, and M. T. C. Sansiviero, " $\mathrm{ZnO} / \mathrm{TiO}_{2}$ semiconductor nanocomposites. Photocatalytic tests," Quimica Nova, vol. 33, no. 1, pp. 85-89, 2010.

[23] G. Marcì, V. Augugliaro, M. J. López-Muñoz et al., "Preparation characterization and photocatalytic activity of polycrystalline $\mathrm{ZnO} / \mathrm{TiO}_{2}$ systems. 2. Surface, bulk characterization, and 4nitrophenol photodegradation in liquid-solid regime," The Journal of Physical Chemistry B, vol. 105, no. 5, pp. 1033-1040, 2001.

[24] Z. Zhang, Y. Yuan, Y. Fang, L. Liang, H. Ding, and L. Jin, "Preparation of photocatalytic nano- $\mathrm{ZnO} / \mathrm{TiO}_{2}$ film and application for determination of chemical oxygen demand," Talanta, vol. 73, no. 3, pp. 523-528, 2007.

[25] J. Tian, L. Chen, Y. Yin et al., "Photocatalyst of $\mathrm{TiO}_{2} / \mathrm{ZnO}$ nano composite film: preparation, characterization, and photodegradation activity of methyl orange," Surface and Coatings Technology, vol. 204, no. 1-2, pp. 205-214, 2009.

[26] J. Tian, J. Wang, J. Dai, X. Wang, and Y. Yin, "N-doped $\mathrm{TiO}_{2} / \mathrm{ZnO}$ composite powder and its photocatalytic performance for degradation of methyl orange," Surface and Coatings Technology, vol. 204, no. 5, pp. 723-730, 2009.

[27] F. Sheng, C. Xu, Z. Jin et al., "Simulation on field enhanced electron transfer between the interface of $\mathrm{ZnO}-\mathrm{Ag}$ nanocomposite," The Journal of Physical Chemistry C, vol. 117, no. 36, pp. 1862718633, 2013.

[28] C. Gu, C. Cheng, H. Huang, T. Wong, N. Wang, and T.-Y. Zhang, "Growth and photocatalytic activity of dendrite-like ZnO@Ag heterostructure nanocrystals," Crystal Growth and Design, vol. 9, no. 7, pp. 3278-3285, 2009.
[29] Y. Han, D. Peng, Z. Xu, H. Wan, S. Zheng, and D. Zhu, “TiO supported Pd@Ag as highly selective catalysts for hydrogenation of acetylene in excess ethylene," Chemical Communications, vol. 49, no. 75, pp. 8350-8352, 2013.

[30] Y. Zheng, L. Zheng, Y. Zhan, X. Lin, Q. Zheng, and K. Wei, "Ag/ZnO heterostructure nanocrystals: synthesis, characterization, and photocatalysis," Inorganic Chemistry, vol. 46, no. 17, pp. 6980-6986, 2007.

[31] Y. Li, W. Xie, X. Hu et al., "Comparison of dye photodegradation and its coupling with light-to-electricity conversion over $\mathrm{TiO}_{2}$ and ZnO," Langmuir, vol. 26, no. 1, pp. 591-597, 2010.

[32] E. R. Macedo, P. S. Oliveira, and H. P. de Oliveira, "Synthesis and characterization of branched polypyrrole/titanium dioxide photocatalysts," Journal of Photochemistry and Photobiology A: Chemistry, vol. 307-308, pp. 108-114, 2015.

[33] M. A. Kanjwal, N. A. M. Barakat, F. A. Sheikh, S. J. Park, and H. Y. Kim, "Photocatalytic activity of $\mathrm{ZnO}-\mathrm{TiO}_{2}$ hierarchical nanostructure prepared by combined electrospinning and hydrothermal techniques," Macromolecular Research, vol. 18, no. 3, pp. 233-240, 2010.

[34] E. S. Araújo, M. L. F. Nascimento, and H. P. de Oliveira, "Influence of Triton X-100 on PVA fibres production by the electrospinning technique," Fibres and Textiles in Eastern Europe, vol. 4, no. 100, pp. 39-43, 2013.

[35] H. P. de Oliveira, J. J. F. Albuquerque Jr., C. Nogueiras, and J. Rieumont, "Physical chemistry behavior of enteric polymer in drug release systems," International Journal of Pharmaceutics, vol. 366, no. 1-2, pp. 185-189, 2009.

[36] H. P. de Oliveira, G. F. Tavares, C. Nogueiras, and J. Rieumont, "Physico-chemical analysis of metronidazole encapsulation processes in Eudragit copolymers and their blending with amphiphilic block copolymers," International Journal of Pharmaceutics, vol. 380, no. 1-2, pp. 55-61, 2009.

[37] H. A. Sharif, A. A. E. Rasha, and Z. Al-B Ramia, "Titanium dioxide content in foodstuffs from the Jordanian market: spectrophotometric evaluation of $\mathrm{TiO}_{2}$ nanoparticles," International Food Research Journal, vol. 22, no. 3, pp. 1024-1029, 2015.

[38] X. Du, Y. Xu, L. Qin, X. Lu, Q. Liu, and Y. Bai, "Simple and rapid spectrophotometric determination of titanium on etched aluminum foils," American Journal of Analytical Chemistry, vol. 5, no. 3, pp. 149-156, 2014.

[39] T. J. Collins, "ImageJ for microscopy," BioTechniques, vol. 43, no. 1, pp. 25-30, 2007.

[40] D. P. Barboriak, A. O. Padua, G. E. York, and J. R. MacFall, "Creation of DICOM - aware applications using Image)," Journal of Digital Imaging, vol. 18, no. 2, pp. 91-99, 2005.

[41] A. N. Kolmogorov, "Sulla determinazione empirica di una legge di distribuzione," Giornale dell'Istituto Italiano degli Attuari, vol. 4, pp. 83-91, 1933.

[42] K. A. Alim, V. A. Fonoberov, M. Shamsa, and A. A. Balandin, "Micro-Raman investigation of optical phonons in $\mathrm{ZnO}$ nanocrystals," Journal of Applied Physics, vol. 97, no. 12, Article ID 124313, 2005.

[43] V. A. Fonoberov and A. A. Balandin, "Interface and confined optical phonons in wurtzite nanocrystals," Physical Review B, vol. 70 , no. 23, pp. 1-4, 2004.

[44] V. A. Fonoberov and A. A. Balandin, "Polar optical phonons in wurtzite spheroidal quantum dots: theory and application to $\mathrm{ZnO}$ and $\mathrm{ZnO} / \mathrm{MgZnO}$ nanostructures," Journal of Physics Condensed Matter, vol. 17, no. 7, pp. 1085-1097, 2005.

[45] T. C. Damen, S. P. S. Porto, and B. Tell, "Raman effect in zinc oxide," Physical Review, vol. 142, no. 2, pp. 570-574, 1966. 
[46] G. R. Hearne, J. Zhao, A. M. Dawe et al., "Effect of grain size on structural transitions in anatase $\mathrm{TiO}_{2}$ : a Raman spectroscopy study at high pressure," Physical Review B, vol. 70, no. 13, Article ID 134102, 10 pages, 2004.

[47] S. Sahoo, A. K. Arora, and V. Sridharan, "Raman line shapes of optical phonons of different symmetries in anatase $\mathrm{TiO}_{2}$ nanocrystals," The Journal of Physical Chemistry C, vol. 113, no. 39, pp. 16927-16933, 2009.

[48] T. Ohsaka, F. Izumi, and Y. Fujiki, "Raman spectrum of anatase, $\mathrm{TiO}_{2}$," Journal of Raman Spectroscopy, vol. 7, no. 6, pp. 321-324, 1978.

[49] M. Horprathum, P. Eiamchai, P. Chindaudom, A. Pokaipisitb, and P. Limsuwan, "Oxygen partial pressure dependence of the properties of $\mathrm{TiO}_{2}$ thin films deposited by $\mathrm{DC}$ reactive magnetron sputtering," Procedia Engineering, vol. 32, pp. 676682, 2012.

[50] M. Landmann, E. Rauls, and W. G. Schmidt, "The electronic structure and optical response of rutile, anatase and brookite $\mathrm{TiO}_{2}$," Journal of Physics: Condensed Matter, vol. 24, no. 19, Article ID 195503, 7 pages, 2012.

[51] J. Yan, G. Wu, N. Guan, L. Li, Z. Li, and X. Cao, "Understanding the effect of surface/bulk defects on the photocatalytic activity of $\mathrm{TiO}_{2}$ : anatase versus rutile," Physical Chemistry Chemical Physics, vol. 15, no. 26, pp. 10978-10988, 2013.

[52] J. Zhang, M. Li, Z. Feng, J. Chen, and C. Li, "UV raman spectroscopic study on $\mathrm{TiO}_{2}$ - I. phase transformation at the surface and in the bulk," Journal of Physical Chemistry B, vol. 110, no. 2, pp. 927-935, 2006.

[53] C. Aprile, L. Maretti, M. Alvaro, J. C. Scaiano, and H. Garcia, "Long-lived (minutes) photoinduced charge separation in a structured periodic mesoporous titania containing 2,4,6triphenylpyrylium as guest," Dalton Transactions, no. 40, pp. 5465-5470, 2008.

[54] D. A. H. Hanaor and C. C. Sorrell, "Review of the anatase to rutile phase transformation," Journal of Materials Science, vol. 46, no. 4, pp. 855-874, 2011.

[55] B. C. Gou, Z. X. Liu, Q. L. Cui, H. B. Yang, Y. N. Zhao, and G. T. Zou, "Raman study of anatase $\left(\mathrm{TiO}_{2}\right)$ at high pressure," High Pressure Research, vol. 1, pp. 185-191, 1989.

[56] S. K. Sharma, J. F. Mammone, and M. F. Nicol, "Raman investigation of ring configurations in vitreous silica," Nature, vol. 292, no. 5819, pp. 140-141, 1981.

[57] I. Bobowska, A. Opasińska, A. Wypych, and P. Wojciechowski, "Synthesis and dielectric investigations of $\mathrm{ZnTiO}_{3}$ obtained by a soft chemistry route," Materials Chemistry and Physics, vol. 134, no. 1, pp. 87-92, 2012.

[58] M. T. C. Sansiviero and D. L. A. De Faria, "Influence of thermal treatment on the photocatalyst nanocomposite $\mathrm{ZnO} / \mathrm{TiO}_{2}$," Quimica Nova, vol. 38, no. 1, pp. 55-59, 2015.

[59] N. T. Nolan, M. K. Seery, and S. C. Pillai, "Crystallization and phase-transition characteristics of sol-gel-synthesized zinc titanates," Chemistry of Materials, vol. 23, no. 6, pp. 1496-1504, 2011. 

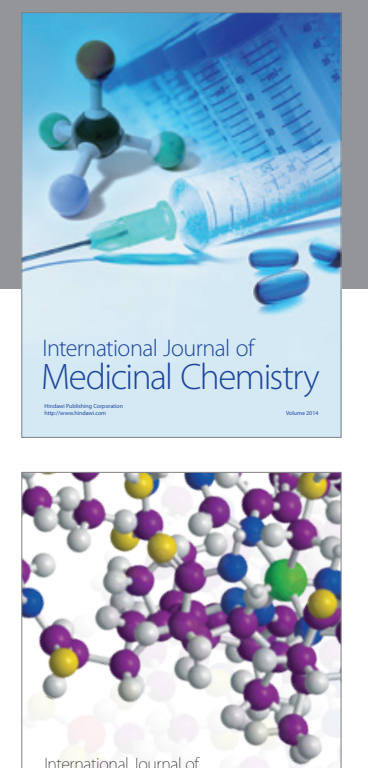

\section{Carbohydrate} Chemistry

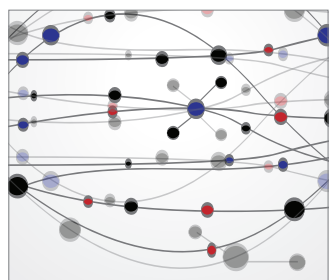

The Scientific World Journal
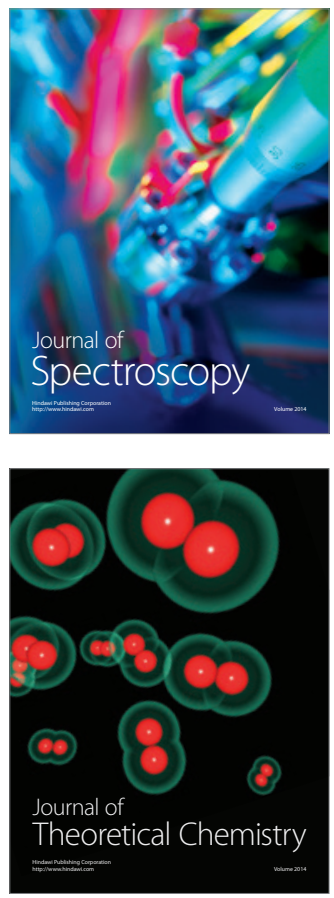
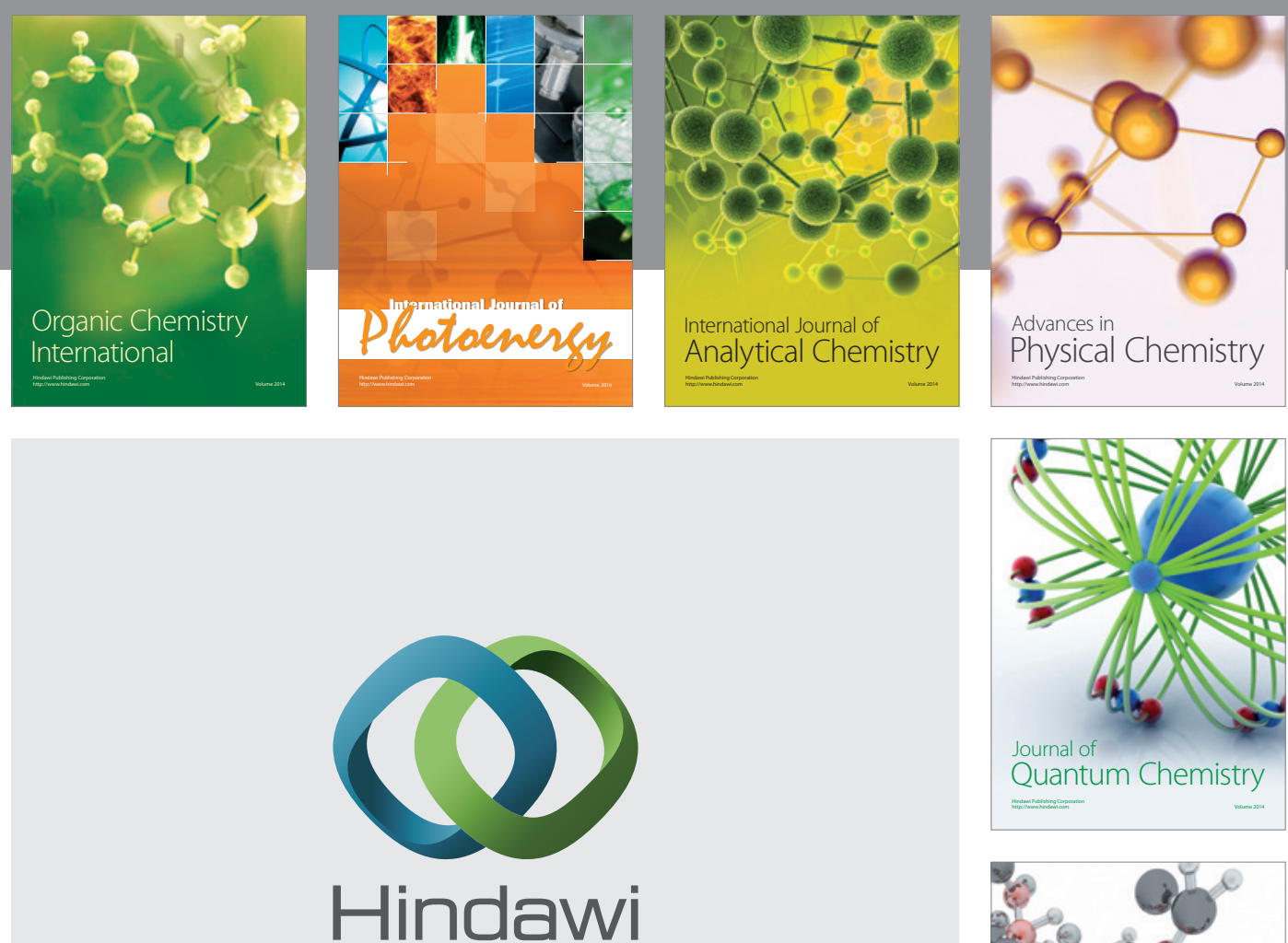

Submit your manuscripts at

http://www.hindawi.com

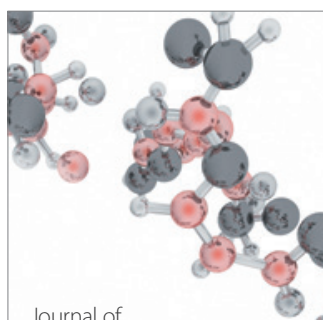

Analytical Methods

in Chemistry

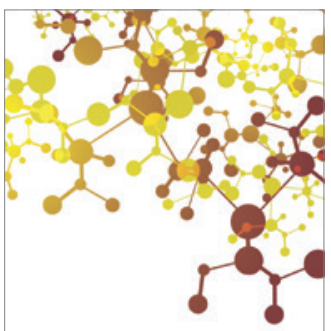

Journal of

Applied Chemistry

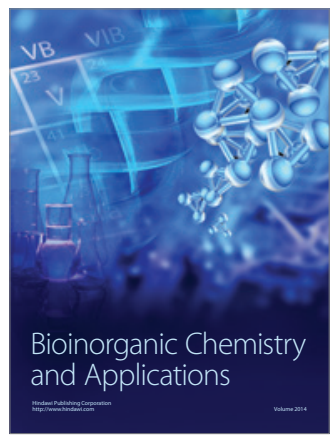

Inorganic Chemistry
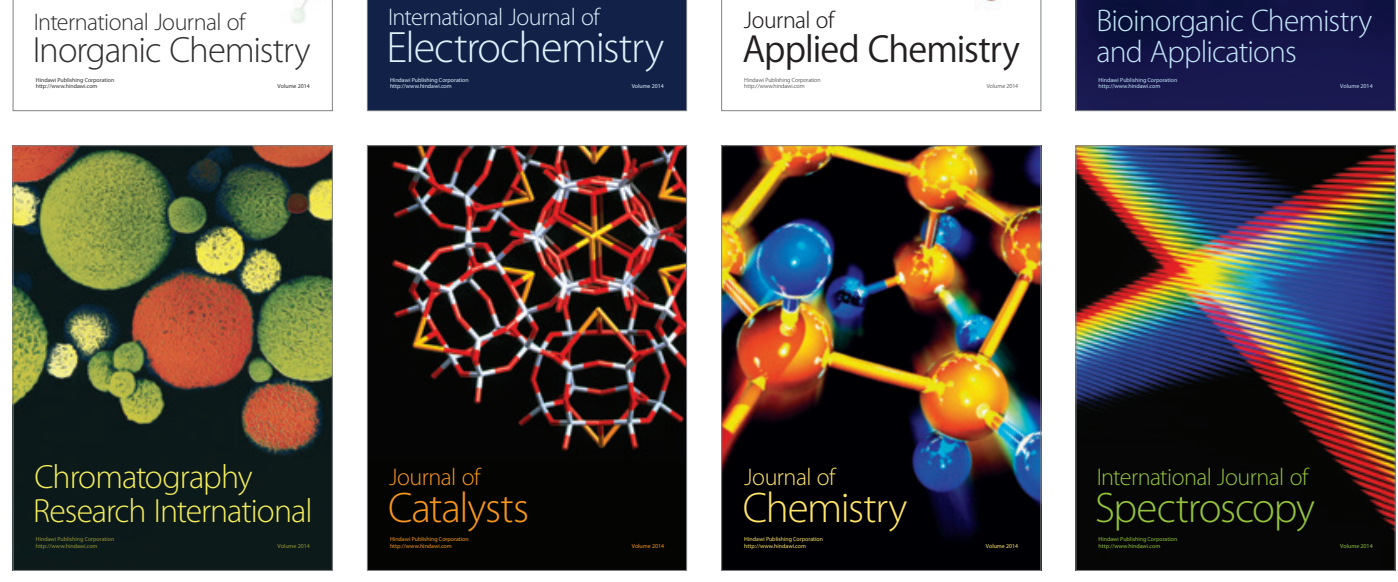